\title{
ESTABLISHMENT OF APPLE AND PEAR TREES IN GRASS
}

\author{
R. L. TAYLOR \\ R.D.2, Upper Moutere, Nelson
}

\begin{abstract}
Summary
Young apple and pear trees made better seasonal growth where grass around them was killed by chemicals or by cultivation. Still better growth was made where both treatments were done. Chemical treatment produced better growth the same season than cultivation, but unless followed by cultivation disposed the trees towards poorer growth the following season. The writer recommends growing vigorous grass around young trees in autumn and winter, killing it in spring, followed by hoeing in early summer.
\end{abstract}

\section{INTRODUCTION}

THERE ARE MANY advantages in planting fruit trees in ground which has been levelled and grassed without further cultivation except close to each tree. Control of vegetation at the base of young trees has long been regarded as essential for satisfactory tree growth. Digging or hoeing around trees is slow, hard work, and on many properties cannot be done so often or so thoroughly as desired Good control of the vegetation can be obtained more quickly and more easily by chemicals now available. To assess the influence of grass-killing chemicals on tree growth trials have been done on the Moutere Hills of Nelson where a large part of the New Zealand export apple crop is grown. The soil is naturally a heavy infertile clay but is capable of considerable improvement. Unlike those of Hewetson (1961) these trials do not attempt to compare different chemicals, but are designed to compare effective chemical treatment with no treatment or with cultivation.

Statistical analyses are given in accordance with Student's $t$ test, and all rates of treatment are given in $\mathrm{lb}$ active ingredient per acre.

CHEMICAL TREATMENT VERSUS NO TREATMENT

Table 1 summarizes five trials in which comparison is made of the seasonal growth of young trees when the grass growing at their base is either killed by chemicals or left untreated. In each trial every tree had previously been treated the same. It is clear that vigorous grass is unfavourable towards tree growth, and that its removal by chemicals in spring leads to better growth. Table 2 summarizes two trials in which better growth was obtained over two seasons from chemical control of vegetation around the same trees each spring.

\section{CHEMICAL TREATMENT VERSUS CULTIVATION}

It is not sufficient that chemical treatment should make trees grow better than those left in grass. To be fully successful chemical control of vegetation must make trees grow as well as cultivation done with moderate thoroughness. In four trials summarized in Table 3 chemical treatment is compared with cultivation. In these trials spraying was done in September and was followed by hoeing as soon as the ground was dry enough. 
As expected, spraying and cultivation both led to improved growth. Trees grew best where spraying was followed by cultivation. This result is important because turf can be hoed three or four times as quickly if the grass is first killed.

It was surprising, however, that spraying should lead to growth so much better than hoeing. This result can be explained by the larger area sprayed than hoed, and by the cover of dead grass reducing the loss of soil moisture.

\section{CARRY-OVER EFFECTS}

In each trial, summarized in Table 4, trees received different treatments the first season but uniform treatment the second season. It would be expected that trees which had made poor growth the first season would continue to grow poorly the second season. It is surprising therefore that the trees stunted by competition from grass should catch up with trees which had the grass killed by chemicals. It is still more surprising that these trees should, in three out of four trials, grow significantly better.

In view of this adverse result, it would be unwise to rely upon chemical treatment only except where there is no alternative but to let the grass grow around the trees. Where cultivation is possible, the only recommendation that can be made on present evidence is to spray first and to cultivate later.

\section{DISCUSSION}

Trenches dug across treated plots in early summer revealed big differences in soil moistures at tree root level according to treatment at the surface. Where grasses were growing vigorously the ground was much drier than where the ground was bare, but where the grasses had been killed in spring the ground was damper. Differences in tree growth the season following spraying or cultivation in spring appear to be due largely to different amounts of soil moisture available to the trees.

Where ground was treated chemically but no cultivation done vegetation failed to establish in the autumn. The following season such ground had deteriorated visibly in soil structure in contrast with ground which had cover over the winter. Where cultivation was done, whether spraying was done or not, vegetation re-established in autumn. The dominant species was often short-rotation ryegrass (Lolium perenne $\times$ L. multiflorum) from wind-blown seed.

The writer is of the opinion that such vegetation growing over the winter is beneficial in maintaining soil structure and after killing by chemicals in spring in providing soil cover to reduce loss of moisture.

Because of the way results have turned out there is a need for further studies in tree growth in which various treatments are applied to the same trees for several years in succession.

NOTE ON CHEMICALS

Sodium dichloropropionate has given somewhat disappointing grass control over six seasons. A weakness of this chemical which has been recognized only in recent years is its loss of efficacy against some grasses such as ryegrass (Lolium spp.) and fog grass (Holcus lanatus) as spring advances, especially where heavy applications of nitrogenous fertilizer have been made. After midSeptember it would be better, in most circumstances, to use paraquat, which appears to be more reliable in its action on grasses. 


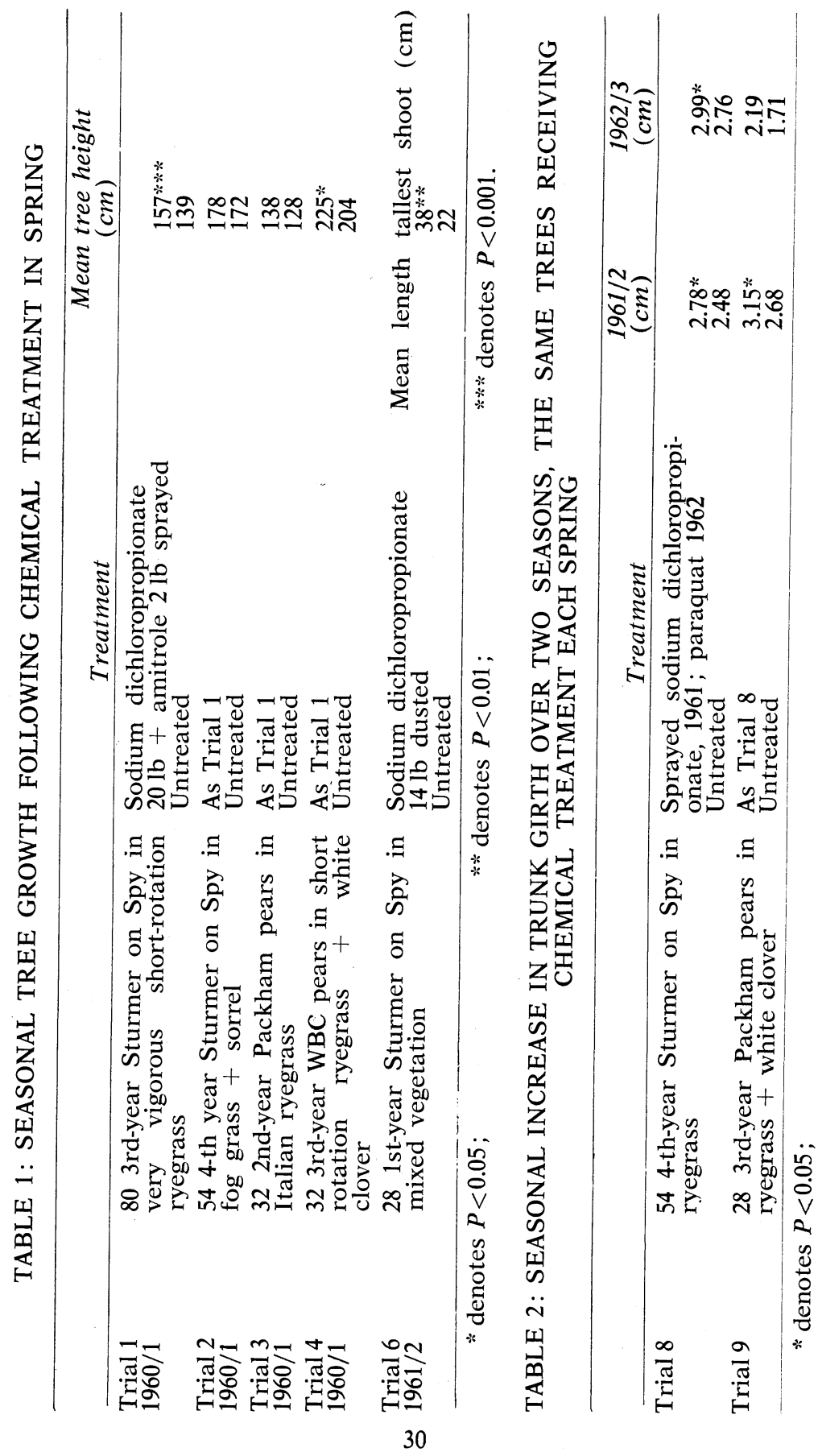




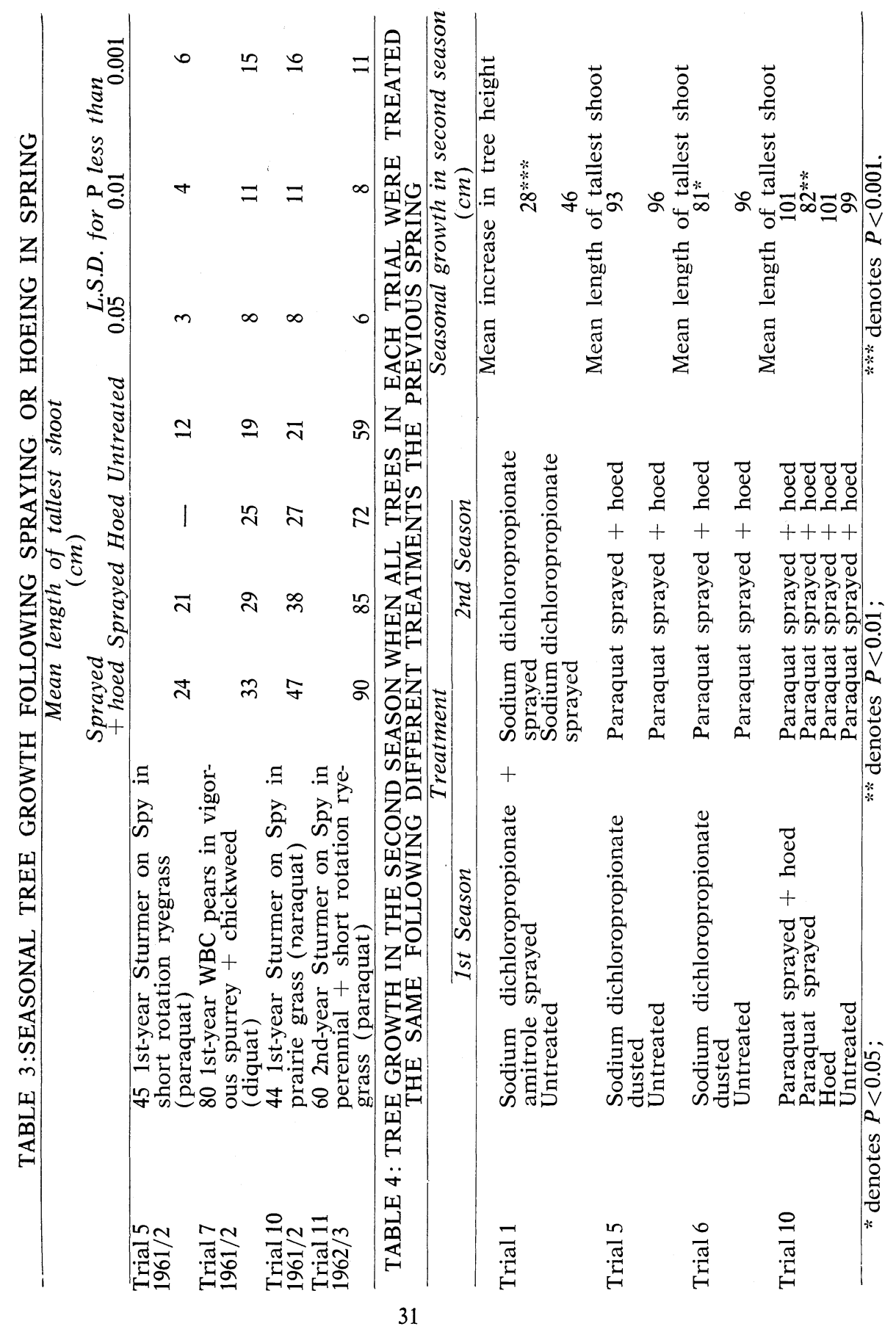


Paraquat is very good against ryegrass but needs two applications to deal with cocksfoot (Dactylis glomerata) and prairie grass (Bromus catharticus). Where these more difficult grasses are present paraquat needs spraying to saturation at $0.04 \%$ active cation.

Apple trees tolerate foliage spraying in spring with this concentration of paraquat surprisingly well in contrast with pears, plums, peaches, and apricots. Table 5 shows good recovery of apple but not pear trees from spraying on October 23, one month after leaves had formed.

TABLE 5: TOLERANCE OF TREES TO PARAQUAT SPRAYED ON TO FOLIAGE

\begin{tabular}{|c|c|c|}
\hline $\begin{array}{l}\text { Mean } 1 \mathrm{l} \\
\text { overall }\end{array}$ & $\begin{array}{l}\text { ngth of tall } \\
\text { spraying }\end{array}$ & $\begin{array}{l}\text { llest shoot at end of season following } \\
\text { with paraquat } 0.04 \% \text { active on } \\
\text { October 23,1962 } \\
(\mathrm{cm})\end{array}$ \\
\hline \multirow{2}{*}{$\begin{array}{l}12 \text { 1st-year } \\
\text { Golden Delicious } \\
\text { on Spy }\end{array}$} & Sprayed & 80 \\
\hline & Untreated & 84 \\
\hline $\begin{array}{l}12 \text { 2nd-year } \\
\text { WBC pears }\end{array}$ & $\begin{array}{l}\text { Sprayed } \\
\text { Untreated }\end{array}$ & $\begin{array}{l}26^{* * *} \\
60\end{array}$ \\
\hline
\end{tabular}

Amitrole has been found a very efficacious but dangerous chemical, giving rise to leaf chlorosis months after application, indicating root uptake. In the U.S.A., on the other hand, amitrole has been extensively tried and no harmful effects are reported by Prof. H. H. Hemphill of Missouri (pers. comm.) and Hewetson (1963). In New Zealand people are urged to proceed cautiously with amitrole at rates above $2 \mathrm{lb}$ on trees up to the 4 th year after transplanting.

Soil sterilants, notably simazine, have been recommended and are in use in young orchards in some countries, but the writer considers them unnecessary, too expensive, and liable to lead to poor soil structure.

\section{REFERENCES}

Hewetson, F. N. 1961: Herbicides for young apple trees. NEWCC. 1963: Herbicides for deciduous orchards. NEWCC. 